Volume. 15, Nomor 1, Juni 2019

\title{
Pengaruh Penerapan Standar Pelayanan Terhadap Minat Pembiayaan Produk BSM Implan di Bank Syariah Mandiri Cabang Gorontalo
}

\author{
Sofhian \\ Nur Shaffitri Hudodo
}

IAIN Sultan Amai Gorontalo

fiantomare@yahoo.co.id

\begin{abstract}
This study aims to determine and analyze the effect of Service Standard Implementation (Self Appearance, Knowledge of Banking Products \& Services, Standards to Communicate with Customers) to the Interests of BSM Implant Financing in Gorontalo Branch Syariah Mandiri Bank partially. And to find out and analyze the influence of the application of service standards (Self Appearance, Knowledge of Banking Products \& Services, Standards for Communicating with Customers) on the Interest of BSM Implant Financing in the Bank Syariah Mandiri Gorontalo Branch simultaneously.This type of research is quantitative research. The population in this study were BSM Implan customers who were doing installments in the 2018 period. And the sample was 70 customers obtained from the BSM Implan 2018 installment customer population. The data collection method was the questionnaire method. This study uses a multiple regression analysis method. And has a significant level of 0.05.From the results of the partial test the self-appearance variable did not significantly influence the interest in financing BSM Implants in the Gorontalo's branch. The testing between knowledge variables of banking products and services to interest in BSM Implan financing showed that the knowledge of banking products \& services had a positive and significant effect on interest BSM Implan financing at the Bank Syariah Mandiri branch of Gorontalo. The partial test results between the standard variables communicating with customers towards the interest of BSM Implan financing show that the standard variable communicating with customers does not have a significant effect on interest in financing BSM Implan in the Bank Syariah Mandiri branch. From the results of simultaneous testing ( $f$ test) between independent variables namely Self-Appearance, Knowledge of Products \& Services, and Communicating with customers on the dependent variable namely interest in BSM Implant financing shows that simultaneously, independent variables, namely the Implementation of Service Standards (Self-Appearance, Knowledge of Banking Products \& Services, Standards for Communicating with Customers) affect the dependent variable namely the interest in financing BSM Implants at the Bank Syariah Mandiri branch of Gorontalo. The determination coefficient shows the magnitude of the influence of the implementation of service standards on the interest in financing BSM Implan products to the Syariah Branch of Gorontalo branch of 0.392 or $39.2 \%$ and the rest is influenced by other factors.
\end{abstract}

Keywords : Self Appearance, Knowledge of Banking Products \& Services, Communication, Interests, Financing of BSM Implants. 


\section{A. Pendahuluan}

\section{Latar Belakang}

Perbankan Syariah merupakan layanan yang harus mampu menjalankan amanah secara profesional serta memiliki frontliners dan bankir dengan keterampilan layanan yang dapat memperkuat citra bisnis berbasis syariah yang menjadi diferensiasinya. Hal itu sangat penting guna memperoleh ridha Allah SWT, memenuhi kebutuhan nasabah, menyikapi perilaku pesaing, serta memenuhi ekspektasi masyarakat yang tinggi terhadap peran dan keberadaan bank syariah.

Layanan yang dilakukan harus berlandaskan etika dan bertujuan ibadah (worship) dengan niat untuk mendapatkan ridha Allah SWT. Siapapun yang akan datang akan dilayani secara baik (welcome), bisa memberikan solusi (solution), harus menimbulkan rasa aman dan nyaman (secure), menguntungkan nasabah dan bank (provitable), serta senantiasa memberikan layanan yang terbaik secara konsisten dengan mengacu service level dan standard operating procedure (concistency). Aspek layanan ini memerlukan operational excellence yang menghendaki adanya standar proses (standard of process) guna membentuk service level yang berpengaruh terhadap standar hasil (standard of result) yang akan dicapai. ${ }^{1}$

Secara umum, standar layanan perbankan syariah meliputi: 1) Standar penampilan petugas, 2) Standar kebersihan dan kerapian ruang kerja, 3) Pengetahuan mengenai produk dan jasa perbankan, 4) Standar komunikasi dengan nasabah, 5) Standar penanganan keluhan nasabah. ${ }^{2}$

Bank Syariah Mandiri cabang Gorontalo sebagai salah satu bank syariah di Provinsi Gorontalo terus berupaya dalam meningkatkan kualitas pelayanan nasabah untuk pencapaian target perusahaan salah satunya dengan meningkatkan kuantitas mitra untuk produk pembiayaan BSM Implan dan peningkatan peforma pelayanan dari marketing hingga admin pelayanan.

Pembiayaan BSM Implan pada Bank Syariah Mandiri merupakan pemberian fasilitas pembiayaan konsumer kepada sejumlah karyawan (kolektif) dengan rekomendasi perusahaan/instansi (approve company), dimana pembayaran angsurannya dikoordinasi oleh perusahaan/instansi melalui pemotongan gaji langsung. Pembiayaan Implan adalah pembiayaan consumer dalam valuta rupiah yang diberikan oleh Bank Syariah Mandiri kepada karyawan tetap yang pengajuannya dilakukan secara masal atau kolektif minimal pengajuan pembiayaan implan di Bank Syariah Mandiri 10 orang dalam suatu perusahaan atau lembaga dan harus ada yang

\footnotetext{
${ }^{1}$ Ikatan Bankir Indonesia, Memahami Bisnis Bank Syariah, (Jakarta: PT Gramedia Pustaka Utama, 2016), hal. 296-297

${ }^{2}$ Ikatan Bankir Indonesia, Memahami Bisnis Bank Syariah, (Jakarta: PT Gramedia Pustaka Utama, 2016), hal. 296-298
} 
penanggung jawabnya meskipun penanggung jawabnya tidak ikut mengajukan pembiayaan tersebut. Tujuan dari pembiayaan implan adalah pembiayaan multiguna (renovasi rumah, pendidikan, pembelian barang konsumtif, dan umroh). Jangka waktu pembiayaan implan di Bank Syariah Mandiri1 s/d 5 tahun (untuk pegawai tetap). ${ }^{3}$

Berbeda dengan pembiayaan lain, terdapat hal yang menarik pada proses pelayanan konsultasi nasabah dengan admin BSM Implan. Jika pada produk pembiayaan pensiun para sales force harus terjun lapangan untuk mencari nasabah, sedangkan Implan tanpa promosi lapangan nasabah pns dan karyawan swasta sendiri yang berinisiatif untuk datang ke Bank Syariah Mandiri cabang Gorontalo. Sambutan admin BSM Implan kepada nasabah pun dapat dinilai seperti kerabat dekat. Wacana yang terdapat ditengah masyarakat adalah bahwa terbatasnya modal oleh karyawan kolektif (PNS) yang pemanfaatannya beragam (multiguna), telah mendorong mereka untuk melakukan pembiayaan BSM Implan. Pilihan ini dilakukan tidak lain dan tidak bukan adalah untuk menerapkan masyarakat sejahtera yang sesuai dengan ketentuan Islam. ${ }^{4}$

Berdasarkan data yang diperoleh dari Bank Syariah Mandiri Cabang Gorontalo sampai saat ini total keseluruhan nasabah BSM Implan sebanyak 112 nasabah.

\section{Tabel 1.1}

\section{Pertumbuhan Jumlah Nasabah Pembiayaan BSM Implan (Pegawai Negeri \& Swasta) Periode 2017-2018}

\begin{tabular}{|c|c|}
\hline Periode & Jumlah \\
\hline Juli - Desember 2017 & 29 \\
\hline Januari - Maret 2018 & 30 \\
\hline April - Juni 2018 & 27 \\
\hline Juli - September 2018 & 16 \\
\hline Oktober - November 2018 & 10 \\
\hline TOTAL & 112 \\
\hline
\end{tabular}

Sumber: Bank Syariah Mandiri Cabang Gorontalo, 21 November 2018

Dari data diatas, dapat dikatakan bahwa jumlah instansi yang bekerja sama dengan BSM

\footnotetext{
${ }^{3}$ Wawancara pada tanggal 21 November 2018 dengan Ibu Misrinda Jusuf, sebagai admin BSM Implan di BSM KC Gorontalo ${ }^{4}$ Wawancara pada tanggal 21 November 2018 dengan Ibu Misrinda Jusuf, sebagai admin BSM Implan di BSM KC Gorontalo
} 
Gorontalo dan pegawainya sudah melakukan pembiayaan pada tahun 2018 terdiri dari 9 instansi dengan total nasabah sebanyak 70. Perjanjian kerjasama instansi diyakini dapat mempengaruhi peningkatan jumlah nasabah pembiayaan BSM Implan yang dapat terjadi pada tiap periode.

\section{Rumusan Masalah}

Berdasarkan uraian latar belakang diatas, masalah dapat dirumuskan sebagai berikut:

1. Apakah standar penampilan diri berpengaruh terhadap minat pembiayaan produk BSM Implan di PT. Bank Syariah Mandiri Cabang Gorontalo?

2. Apakah standar pengetahuan produk dan jasa perbankan berpengaruh terhadap minat pembiayaan produk BSM Implan di PT. Bank Syariah Mandiri Cabang Gorontalo?

3. Apakah standar berkomunikasi degan nasabah berpengaruh terhadap minat pembiayaan produk BSM Implan di PT. Bank Syariah Mandiri Cabang Gorontalo?

4. Apakah standar pelayanan berpengaruh secara simultan terhadap minat pembiayaan BSM Implan di PT. Bank Syariah Mandiri Cabang Gorontalo?

\section{B. Kajian Teori}

\section{Penerapan Standar Pelayanan}

Pelayanan adalah suatu proses bantuan kepada orang lain dengan cara- cara tertentu yang memerlukan kepekaan dan hubungan interpersonal agar tercipta kepuasan dan keberhasilan hakikat pelayanan umum adalah sebagai berikut:

1. Meningkatkan mutu dan produktivitas pelaksanaan tugas dan instansi pemerintah di bidang pelayanan umum.

2. Mendorong upaya mengefektifkan sistem dan tata laksana pelayanan sehingga pelayanan umum dapat diselenggarakan secara lebih berdaya guna dan berhasil guna (efisien dan efektif).

3. Mendorong tumbuhnya kretifitas, prakarsa dan peran serta masyarakat dalam pembangunan serta meningkatkan kesejahteraan masyarakat luas. ${ }^{5}$

Menurut Siagian, pelayanan secara umum adalah rasa menyenangkan yang diberikan kepada orang lain disertai kemudahan-kemudahan, dan memenuhi segala kebutuhan mereka. Sedangkan pelayanan menurut Munir pelayanan adalah aktivitas yang dilakukan seseorang atau sekelompok orang dengan landasan faktor material melalui sistem, prosedur, dan metode tertentu

\footnotetext{
${ }^{5}$ Nofri Boy Sandi, Analisis Pengaruh Pelayanan, Konsultasi, dan Pengawasan Account Representative Terhadap Kepatuhan Wajib Pajak : Skripsi, Jurusan Akuntansi Fakultas Ekonomi dan Bisnis Universitas Islam Negeri Syarif Hidayatullah Jakarta, 2010, hlm.39
} 
dalam rangka memenuhi kebutuhan orang lain sesuai dengan haknya. ${ }^{6}$

Pelayanan diartikan sebagai setiap kegiatan yang menguntungkan dalam suatu kumpulan kesatuan, menawarkan kepuasan meskipun hasilnya tidak terikat pada suatu produk secara fisik. Dan menurut Giroonroos dalam Hastono Pelayanan adalah suatu aktivitas atau serangkaian aktivitas yang bersifat tidak kasat mata (tidak dapat diraba) yang terjadi sebagai akibat adanya interaksi antara konsumen dengan karyawan atau hal-hal lain yang disediakan oleh perusahaan.

Pelayanan merupakan suatu cara untuk membandingkan persepsi layanan yang diterima pelanggan dengan layanan yang sesungguhnya. Apabila layanan yang diharapkan pelanggan lebih besar dari layanan yang nyata-nyata diterima pelanggan maka dapat dikatakan bahwa layanan tidak bermutu, sedangkan jika layanan yang diharapkan pelanggan lebih rendah dari layanan yang nyata-nyata diterima pelanggan, maka dinyatakan pelayanan bermutu, dan apabila layanan yang diterima pelanggan sama dengan yang diharapkan maka layanan tersebut dapat dikatakan memuaskan. Dengan demikian, pelayanan merupakan suatu cara untuk mengetahui seberapa jauh perbedaan antara kenyataan dan harapan pelanggan atas layanan yang diterima. ${ }^{7}$

Rangkaian kegiatan terpadu yang dilakukan meningkatkan pelayanan adalah sebagai berikut:

\section{Pelayanan umum sederhana}

Pelayanan umum berkualitas apabila pelaksanaannya tidak menyulitkan, prosedurnya tidak banyak seluk-beluknya, persyaratan mudah dipenuhi pelanggan, tidak bertele-tele, tidak mencari kesempatan dalam kesempitan.

\section{Pelayanan umum yang terbuka}

Aparatur yang bertugas melayani pelanggan harus memberikan penjelasan sejujur-jujurnya, apa adanyaa dalam peraturan dan norma, tidak menakut- nakuti, jangan timbl keinginan mengharapkan imbalan dari pelanggan. Standar pelayanan harus diumumkan, ditempel pada pintu utama kantor.

\section{Pelayanan umum yang lancar}

Untuk menjadi lancar diperlukan sarana yang menunjang kecepatan dalam menghasilkan output.

4. Pelayanan umum yang dapat disajikan secara tepat

\footnotetext{
${ }^{6}$ Julita, Menuju Kepuasan Pelanggan Melalui Penciptaan Kualitas Pelayanan, Jurnal Ilmiah "Manajemen dan Bisnis", Vol. 01, No.01, 2001, hlm. 43

${ }^{7}$ Abdul Waris, Pengaruh Kualitas Pelayanan dan Penerapan Prinsip-Prinsip Syariah Terhadap Minat Hotel Syariah (Studi Kasus pada Hotel Graha Agung) : Skripsi, Fakultas Ekonomi \& Bisnis Islam IAIN Walisongo Semarang, 2010, hlm. 30
} 
Yang dimaksud dengan tepat adalah tepat arah, tepat sasaran, tepat waktu, tepat jawaban dan tepat dalam memenuhi janji.

5. Pelayanan umum yang lengkap

Lengkap berarti tersedia apa yang diperlukan oleh pelanggan. Untuk dapat menjamin pelayanan yang berkualitas harus didukung sumber daya manusia dan sarana yang tersedia.

6. Pelayanan yang wajar

Pelayanan umum yang wajar berarti tidak ditambah-tambah menjadi pelayanan yang bergaya mewah, tidak dibuat-buat, pelayanan biasa seperlunya sehingga tidak memberatkan pelanggan.

7. Pelayanan umum yang terjangkau

Dalam memberikan pelayanan, uang retribusi dari pelayanan yang diberikan harus dapat dijangkau oleh pelanggan. ${ }^{8}$

Tercapainya standar pelayanan sangat erat kaitannya dengan kualitas pelayanan. Kualitas pelayanan adalah keseluruhan corak dan karakteristik dari sebuah jasa yang menunjang kemampuan untuk memuaskan pelanggan baik secara angsung maupun tidak langsung.

Menurut Parasuraman, kualitas pelayanan adalah suatu ukuran bagaimana pelayanan didistribusikan sesuai ddengan ekspektasi pelanggan. Penyampaian kualitas pelayanan berarti penyelarasan ekspektasi pelanggan kedalam sesuatu hal yang konsisten. ${ }^{9}$

Ada hal yang penting tentang pengertian kualitas pelayanan menurut Boediono, yaitu:

a. Kualitas jasa lebih sulit diveluasi dibandingkan dengan mengevaluasi barang berwujud dan oleh sebab itu kriteria untuk mengevaluasi akan lebih sulit untuk ditetapkan.

b. Dalam mengevaluasi jasa yang diberikan bukan berdasarkan hasil akhirnya saja, melainkan jasa penilaian bagaimana proses penyampaian dilaksanakan.

c. Kriteria dalam penentuan jasa tersebut akhirnya dikembalikan pada pelanggan, pandangan terhadap kualitas suatu jasa pelayanan dimulai dari bagaimana pemberi jasa itu dapat memenuhi harapan pelanggan, kemudian dilanjutkan dengan bagaimana seharusnya pemberi jasa tersebut menampilkan performa. ${ }^{10}$

\footnotetext{
${ }^{8}$ Nofri Boy Sandi, Analisis Pengaruh Pelayanan, Konsultasi, dan Pengawasan Account Representative Terhadap Kepatuhan Wajib Pajak : Skripsi, Jurusan Akuntansi Fakultas Ekonomi dan Bisnis Universitas Islam Negeri Syarif Hidayatullah Jakarta, 2010 , hlm.39

${ }^{9}$ Rahmayanti Lisa, Pengaruh Kualitas Layanan Rawat Inap terhadap Kepuasan Pasien Rumah Sakit Bunda Margonda Depok : Skripsi, Fakultas Ekonomi dan Bisnis Univesitas Indonesia, Depok, 2009. hlm. 16

${ }^{10}$ Nofri Boy Sandi, Analisis Pengaruh Pelayanan, Konsultasi, dan Pengawasan Account Representative Terhadap Kepatuhan Wajib Pajak : Skripsi, Jurusan Akuntansi Fakultas Ekonomi dan Bisnis Universitas Islam Negeri Syarif Hidayatullah Jakarta, 2010, hlm. 40
} 
Volume. 15, Nomor 1, Juni 2019

Halaman. 68-88
Pengaruh Penerapan Standar Pelayanan

Terhadap Minat Pembiayaan Produk BSM Implan

di Bank Syariah Mandiri Cabang Gorontato

Menurut Zeithaml, mengukur kualitas pelayanan melalui lima dimensi, yaitu:

a. Reliability

Kemampuan untuk memberikan pelayanan yang akurat sesuai dengan janji.

b. Responsiveness

Kesediaan membantu pelanggan dan menyediakan pelayanan yang sesuai.

C. Assurance

Pengetahuan dan kehormatan seorang karyawan, serta kemampuannya untuk memberikan keyakinan dan kepercayaan.

d. Emphaty

Peduli, memberikan perhatian secara personal kepada pelanggan terkait kebutuhannya.

e. Tangibels

Penampilan dari fasilitas fisik, peralatan, personil, dan alat-alat tulis yang digunakan untuk mennjang pelayanan. ${ }^{11}$

Layanan yang diberikan harus mencerminkan sikap kerja seorang profesional yang mempunyai keahlian, kesungguhan hati, kompetensi emosional yang tinggi, kemampuan melakukan yang terbaik dengan cara terbaik, sikap tidak melanggar etika dan peraturan, serta menjadikan bidang yang digeluti sebagai penghidupan. ${ }^{12}$

Perilaku layanan yang ditampilkan mesti bersentuhan dengan keihklasan sehingga mudah terkristalisasi menjadi budaya layanan (service culture) sebagai kewajiban seorang muslim. Layanan yang diberikan bersifat proaktif dan cepat serta harus dituangkan dalam bentuk service level agreement bagi pelakunya sebagai wujud anjuran Rasulullah Muhammad saw.

Bank syariah sebagai bank yang berlandaskan Al-Qur'an dan hadits memiliki konsekuensi yang berbeda dibandingkan dengan penampilan karyawan bank konvensional, terutama bagi karyawan perempuan seperti yang

diungkapkan dalam QS. Al-Ahzab : 59

"Hai Nabi katakanlah kepada istri-istrimu, anak-anak perempuanmu, dan istri-istri yang mukmin: "Hendaklah mereka mengulurkan jilbabnya ke seluruh tubuh mereka." Yang demikian itu supaya mereka lebih mudah untuk dikenal, karena itu mereka tidak diganggu.Dan Allah adalah Maha Pengampun lagi Maha Penyayang.,"13

\footnotetext{
11 Zeithaml, Service Marketing: Integrating Customer Focus Across The Firm, Fifth Edition, (New York: McGraw-Hill Companies, 2009), hlm. 111

${ }^{12}$ Ikatan Bankir Indonesia, Memahami Bisnis Bank Syariah, (Jakarta: PT Gramedia Pustaka Utama, 2016), hlm. 298 426

${ }^{13}$ Departemen Agama RI, Al-Qur'an dan Terjemahnya Yasmina, (Bandung: PT Sygma Examedia Arkanleema, 2009), hlm.
} 
Penampilan diri tidak hanya dalam bentuk fisik, tetapi harus dilengkapi dengan perilaku yang baik dan sopan serta menyenangkan ketika memberikan layanan. Hal tersebut erat dengan tuntutan Islam agar seorang muslim wajib membahagiakan orang lain.

\section{Standar Pengetahuan Produk dan Jasa Perbankan}

Produk perbankan syariah berbeda dengan bank konvensional karena produknya lebih variatif, antara lain jual beli, sewa-menyewa, sewa beli, gadai, pembiayaan bagi hasil, kemitraan modal, gadai, sukuk, dan anjak piutang dengan keanekaragaman akad. Keberagaman produk tersebut menuntut penguasaan fikih oleh para karyawan terkait produk yang ditawarkan selain teknis perbankan secara umum. Sebagai contoh, seorang costumer service harus mampu menjelaskan, antara lain, perbedaan prinsip bank syariah dengan konvensional, akad-akad yang berlaku untuk produk tabungan, deposito, giro, pembiayaan, dan electronic banking. Seorang teller harus menguasai transaksi, seperti setoran tunai, penarikan tunai dan pemindahbukuan, kiriman uang, kliring, serta verifikasi data nasabah selain prinsip syariah. ${ }^{14}$

Penguasaan tentang produk dan jasa beserta prinsip syariah yang terkandung merupakan muatan yang harus dikuasai frontliner dan karyawan bank syariah. Apalagi nasabah yang datang ingin mendapatkan diferensiasi layanan agar terhindar dari riba, spekulasi, disamping keinginan untuk bermitra.

Karyawan bank syariah harus menjadi problem solver yang bermanfaat untuk nasabah yang berorientasi dunia dan akhirat sebagaimana yang diungkapkan hadits berikut.

Dari Abu Hurairah ra., dari Nabi saw., beliau bersabda : "Siapa saja yang menghilangkan satu kesulitan dari beberapa kesulitan yang dialami orang mukmin, maka Allah akan menghilangkan satu kesulitan dari beberapa kesulitannya pada hari kiamat. Siapa saja yang memudahkan urusan orang yang mengalami kesulitan, maka Allah akan memudahkan urusannya baik didunia maupun di akhirat. Siapa saja yang menutupi kejelekan seorang muslim, maka Allah akan menutupi kejelekannya di dunia dan di akhirat,dan Allah senantiasa memberi pertolongan kepada hamba-Nya selama ia menolong saudaranya..." (HR. Muslim) $^{15}$

\section{Standar Berkomunikasi dengan Nasabah}

Komunikasi yang baik dengan nasabah dapat membangun kesan positif terhadap bank sehingga turut membantu terbentuknya nasabah yang loyal (loyal customer) yang berpengaruh terhadap pertumbuhan bisnis (bussiness growth), profit, dan kelangsungan uusaha (sustainability).

\footnotetext{
${ }^{14}$ Ikatan Bankir Indonesia, Memahami Bisnis Bank Syariah, (Jakarta: PT Gramedia Pustaka Utama, 2016), hlm. $304-305$

${ }^{15}$ An-Nawawi, Al-Imam Abi Zakaria Yahya bin Syarof, Terjemah Riyadhus Shalihin jilid 1, (Jakarta: Pustaka Amani, 1994), hlm. 267-268
} 
Prinsip komunikasi dalam Islam yang harus menjadi acuan adalah qaulan sadida (berkata yang benar agar dapat dipercaya), qaulan ma'rufa (bertutur kata yang baik sebagai bentuk tata krama), qaulan layyina (berbicara lemah lembut agar bisa diterima), qaulan maisura (berbicara yang pantas, tidak merendahkan orang lain), qaulan baligha (komunikasi yang efektif agar informatif), dan qaulan karima (menghargai dan menghormati perasaan orang lain). ${ }^{16}$

Komunikasi yang dibangun ketika melayani nasabah bank syariah harus mendasar, transparan, dan saling menguntungkan. Apalagi pemahaman masyarakat tentang bank syariah belum sebaik pemahaman terhadap bank konvensional sehingga karyawan bank syariah dituntut untuk menguasai prinsip dasar bank syariah, model akad, serta product konwledge yang berbeda dengan produk bank konvensioanl. Selain itu, produk harus dikomunikasikan secara jelas dan terbuka terkait jenis barang, margin keuntungan, perhitungan bagi hasil, dan hal penting lain untuk menghindari asymetric information. ${ }^{17}$

Lakukan komunikasi secara rileks,sapalah nasabah dengan nama yang disenanginya, serta berlemah lembutlah selama berinteraksi sebagaimana

perintah Al-Qur'an

"Hai orang-orang yang beriman, janganlah sekumpulan orang laki- laki merendahkan kumpulan yang lain, boleh jadi yang ditertawakan itu lebih baik dari mereka. Dan jangan pula sekumpulan perempuan merendahkan kumpulan lainnya, boleh jadi yang direndahkan itu lebih baik. Dan janganlah suka mencela dirimu sendiri dan jangan memanggil dengan gelaran yang mengandung ejekan. Seburuk- buruk panggilan adalah (panggilan) yang buruk sesudah iman dan barangsiapa yang tidak bertobat, maka mereka itulah orang-orang yang zalim"(QS. Al-Hujurat: 11). ${ }^{18}$

Dalam membangun komunikasi kepada nasabah, pegawai bank juga dituntut untuk mampu menghadapi pengaduan dan keluhan nasabah dengan respon positif. Pengaduaan nasabah merupakan ungkapan ketidakpuasan nasabah yang disebabkan oleh adanya potensi kerugian finansial yang diduga akibat kesalahan atau kelalaian bank. Penanganannya perlu dilakukan secara bijaksana karena keluhan yang disampaikan dapat meruncing kembali bila penyelesaiannya tidak cepat, akurat, dan menimbulkan masalah lain. ${ }^{19}$

Penanganan yang diberikan harus cepat, tepat, dan memuaskan dengan memperhatikan

\footnotetext{
${ }^{16}$ Ikatan Bankir Indonesia, Memahami Bisnis Bank Syariah, (Jakarta: PT Gramedia Pustaka Utama, 2016), hal. 305

${ }^{17}$ Ibid., hlm. 305-306

18 Departemen Agama RI, Al-Qur'an dan Terjemahnya Yasmina Syaamil quran, (Bandung: PT Sygma Examedia Arkanleema, 2009), hlm. 516

${ }^{19}$ Ikatan Bankir Indonesia, loc.cit
} 
beberapa hal berikut:

Berempati dalam menerima keluhan (emphaty)

Ikut merasakan apa yang dialami pihak yang menghadapi masalah, menyediakan waktu dan memberikan perhatian khusus guna mendengarkan keluhannya, serta mencarikan jalan keluar hingga tuntas.

1. Kecepatan memberikan tanggapan (Quick response)

Kecepatan dan ketepatan merupakan hal yang sangat penting dalam menangani komplain karena dapat meredam atau menghilangkan pemikiran negatif yang dialami si penyampai keluhan. Respons yang cepat, tepat, dan tuntas merupakan tindakan recovery yang dapat menambah kepercayaan nasabah (problem free).

2. Permintaan maaf (apology)

Permintaan maaf merupakan ungkapan yang harus disampaikan pada saat pertama kali merespons permasalahan yang diadukan oleh nasabah. Pernyataan tersebut merupakan kompensasi psikologis yang layak diterima oleh nasabah yang mengalami tekanan akibat persoalan. Permintaan maaf juga wujud pengakuan terhadap kesalahan yang telah dilakukan, sikap berjanji akan mengatasi, dan berkomitmen agar tidak terulang.

3. Kredibilitas (Credibility)

Kredibilitas merupakan suatu pertaruhan ketika menangani persoalan, yaitu akan menaikkan reputasi jika mampu mengatasinya, atau merusak citra perusahaan jika tidak bisa mengatasi persoalan secara baik. Kredibilitas berkaitan erat dengan kepuasan nasabah dan sangat efektif untuk prmosi word of mouth. ${ }^{20}$

4. Perhatian (attentiveness)

Memberikan perhatian merupakan hal penting ketika berinteraksi dengan si penyampai keluhan karena menyangkut kepercayaan terhadap orang dan bukan kepada prosedur. Komunikasi yang dibangun antara pihak yang melakukan komplain dengan si pemberi layanan merupakan konstruksi kunci dalam pembahasan yang dapat memengaruhi penyelesaian masalah. ${ }^{21}$ Peraturan Bank Indonesia Nomor 7/7/PBI Tahun 2005 telah menetapkan standar waktu dan mekanisme penyelesaian pengaduan nasabah sebagai bentuk perlindungan

${ }^{20}$ Ibid., hlm. 306-307

${ }^{21}$ Ikatan Bankir Indonesia, Memahami Bisnis Bank Syariah, (Jakarta: PT Gramedia Pustaka Utama, 2016), hlm. 307 
konsumen. Bank wajib menetapkan kebijakan dan memiliki prosedur tertulis menyangkut:

1. Penerimaan pengaduan.

2. Penanganan dan penyelesaian pengaduan.

3. Pemantauan penanganan dan penyelesaian pengaduan.

Catherine Devrye dalam bukunya Good Service is Good Business menyimpulkan bahwa formula SERVICE itu adalah: ${ }^{22}$

1. Seelf Esteem (memberi nilai pada diri sendiri)

Servis berasal dari orang-orang, bukan dari perusahaan. Jika para karyawan merasa enak tentang diri mereka sendiri dan kepada siapa mereka bekerja, pandangan positif tersebut akan menular kepada para konsumen.

2. Exceed Expectation (melampaui yang diharapkan)

Tentukan, penuhi, lampauilah yang diharapkan untuk menguasai pasar.

3. Recover (rebut kembali)

Ada sebuah peluang untuk memperbaiiki kesalahan dan merebut konsumen, jika telah mengidentifikasi permasalahannya.

4. Vision (rencanakan masa depan sekarang jjuga)

Mampu menerima berbagai perubahan perilaku konsumen, serta megantisipasi, serta menyambut baik perubahan.

5. Improve (peningkatan)

Lakukan peningkatan secara kontinyu, kalau tidak pesaing munyusul.

6. Care (perhatian)

Anda tidak pernah menang berbantahan dengan konsumen. Memberikan perhatian yang tulus merupakan sikap yang sangat menentukan.

7. Empower (pemberdayaan)

Pemberdayaan menyangkut mengajari karyawan "bagaimana memancing" ${ }^{23}$

\section{Faktor - Faktor yang Mempengaruhi Minat Pembiayaan}

Menurut Kotler, dalam mengambil pembiayaan dapat diasumsikan sebagai minat beli, merupakan perilaku yang muncul sebagai respon terhadap objek yang menunjukkan keinginan

\footnotetext{
${ }^{22}$ Ibid., hlm. 307

${ }^{23}$ Ikatan Bankir Indonesia, Memahami Bisnis Bank Syariah, (Jakarta: PT Gramedia Pustaka Utama, 2016), hlm., 308
} 
pelanggan untuk melakukan penelitian. ${ }^{24}$

Minat beli/pembiayaan digambarkan sebagai situasi seorang sebelum melakukan tindakan, dalam hal ini adalah pembiayaan. Maksudnya adalah situasi yang timbul sebelum keputusan dicetuskan, apakah anggota akan membeli atau tidak jadi membeli. Keputusan pembelian/pembiayaan atau minat belinya muncul dengan diawali dari adanya rangsangan, dari rangsangan ini kemudian melewati berbagai proses yang kemudian sampai pada keputusan nasabah, apakah akan membeli atau tidak membeli. Berikut model perilaku konsumen oleh Philip Kohler mengenai tahap-tahap keputusan pembelian/pembiayaan. ${ }^{25}$

${ }^{24}$ Philip Kotler, Manajemen Pemasaran edisi Milenium I, (Jakarta: PT Prenhalindo, 2002) hlm. 101

25 Ali Chamidun, Analisis Faktor-Faktor yang Mempengaruhi Minat UMKM Mengajukan Pembiayaan pada Lembaga Keuangan Syariah : Skripsi, Jurusan Perbankan Syariah Fakultas Syariah dan Ekonomi Islam STAIN Salatiga Jawa Tengah, 2015, hIm. 39 
Volume. 15, Nomor 1, Juni 2019

Halaman. 68-88
Pengaruh Penerapan Standar Pelayanan

Terhadap Minat Pembiayaan Produk BSM Implan

di Bank Syariah Mandiri Cabang Gorontato

Tabel 2.1

Model Perilaku Pembelian/Pembiayaan

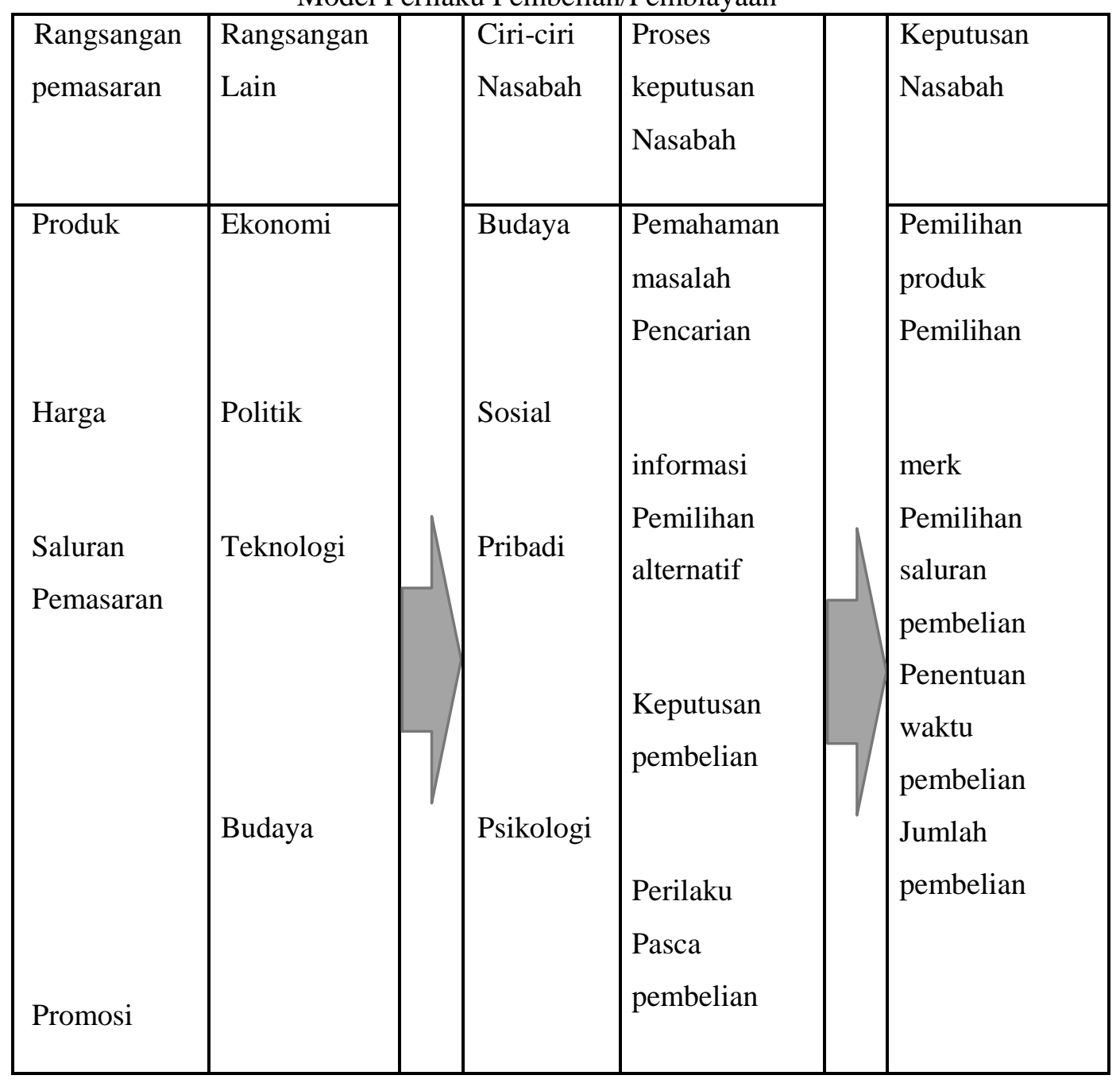

Dari tabel 2.1 sebelum sampai pada minat pembelian/pembiayaan, terlebih dahulu nasabah akan menerima rangsangan atau stimuli yang mereka terima dari para pemasar yang diberikan melalui iklan dan media pemasar lainnya setelah anggota menyadari kebutuhan yang dibutuhkannya. Dan setelah menerima rangsangan tersebut nasabah akan mulai mengevaluasi berdasarkan pengalaman dan persepsi mereka. Namun dalam proses ini para nasabah juga akan menerima faktor-faktor yang akan mempengaruhi minatnya, apakah itu dari keluarga, budaya, ataupun kelompok sosial yang kemudian membantu menyaring berbagai pilihan yang 
ditawarkan. $^{26}$

Faktor - faktor yang mempengaruhi minat, secara garis besar dikelompokkan menjadi dua yaitu (1) dari dalam diri individu yang bersangkutan (misal: bobot, umur, jenis kelamin, pengalaman, perasaan mampu, kepribadian), dan (2) berasal dari luar mencakup lingkungan keluarga, sekolah dan masyarakat. Crow dan Crow berpendapat ada 3 faktor timbulnya minat, yaitu:

1. Dorongan dari dalam individu, misal dorongan untuk makan akan membangkitkan minat untuk bekerja atau mencari penghasilan, minat terhadap produksi makanan dan lain-lain.

2. Motif sosial, dapat menjadi faktor yang membangkitkan minat untuk melakukan aktifitas tertentu.

3. Faktor emosional, minat mempunyai hubngan yang erat dengan emosi. ${ }^{27}$ Jika dikembalikan pada minat keputusan pembelian/mengajukan

pembiayaan, terdapat beberapa faktor yang dapat mempengaruhinya, antara lain:

a. Faktor budaya

Budaya mampu mempengaruhi keputusan pengajuan pembiayaan. Faktor budaya ini meliputi budaya agama, ras, kebangsaan, daerah geografis, strata sosial dan lain sebagainya.

b. Faktor sosial

Pengajuan pembiayaan juga dipengaruhi oleh faktor sosial, dan faktor sosial ini

meliputi kelompok acuan, keluarga, serta peran dan status sosial.

C. Faktor pribadi

Keputusan pengajuan pembiayaan juga dipengaruhi oleh karakterisik pribadi. Karakteristik tersebut meliputi usia, siklus hidup, pekerjaan, keadaan ekonomi, gaya hidup serta kepribadian pembeli.

d. Faktor psikologis

Faktor psikologi dipengaruhi oleh motivasi (kebutuhan pendorong seseorang anggota untuk bertindak), persepsi (proses seseorang memilih, mengorganisasikan, dan menginterpretasi masukan-masukan informasi guna menciptakan gambaran dunia yang memiliki arti), pembelajaran (perubahan perilaku seseorang yang timbul dari pengalaman), serta keyakinan (gambaran yang dianut seseorang tentang suatu hal) dan sikap (evaluasi, perasaan emosional, dan kecenderungan tindakan yang menguntungkan atau tidak menguntungkan dan bertahan

${ }^{26}$ Ibid., hlm. 39

27 Ali Chamidun, Analisis Faktor-Faktor yang Mempengaruhi Minat UMKM Mengajukan Pembiayaan pada Lembaga Keuangan Syariah : Skripsi, Jurusan Perbankan Syariah Fakultas Syariah dan Ekonomi Islam STAIN Salatiga Jawa Tengah, 2015, hlm. 3 
lama dari seseorang terhadap suatu obyek atau gagasan). ${ }^{28}$

\section{Hasil Peneltian}

\section{Pembahasan Hasil Penelitian}

\begin{tabular}{|c|c|c|}
\hline & Hipotesis & Kesimpulan \\
\hline H1 & $\begin{array}{l}\text { Standar Penampilan Diri (X1) berpengaruh secara } \\
\text { parsial dan signifikan terhadap minat pembiayaan } \\
\text { BSM Implan (Y) di Bank Syariah } \\
\text { Mandiri Cabang Gorontalo. }\end{array}$ & Ditolak \\
\hline H2 & $\begin{array}{l}\text { Standar Pengetahuan Produk \& Jasa Perbankan } \\
\text { (X2) berpengaruh secara parsial dan signifikan } \\
\text { terhadap minat pembiayaan BSM Implan (Y) di } \\
\text { Bank Syariah Mandiri } \\
\text { Cabang Gorontalo. }\end{array}$ & Diterima \\
\hline H3 & $\begin{array}{l}\text { Standar berkomunikasi dengan nasabah (X3) } \\
\text { berpengaruh secara parsial dan signifikan terhadap } \\
\text { minat pembiayaan BSM Implan di } \\
\text { Bank Syariah Mandiri Cabang Gorontalo }\end{array}$ & Ditolak \\
\hline H4 & $\begin{array}{l}\text { Standar Pelayanan berpengaruh secara simultan } \\
\text { terhadap minat pembiayaan BSM Implan di Bank } \\
\text { Syariah Mandiri Cabang } \\
\text { Gorontalo. }\end{array}$ & Diterima \\
\hline
\end{tabular}

\section{Pengaruh Penampilan Diri Terhadap Minat Pembiayaan BSM Implan di Bank Syariah Mandiri Cabang Gorontalo.}

Penampilan diri pegawai dapat diartikan sebagai ukuran guna menjaga citra perusahaan karena dilihat dan dinilai oleh khalayak dan diwujudkan dalam bentuk perilaku yang baik dan sopan serta menyenangkan ketika memberikan layanan.

Hasil penelitian ini menunjukkan variabel penampilan diri tidak berpengaruh signifikan

\footnotetext{
${ }^{28}$ Eva Roviana, Analisis Pengaruh Persepsi Harga atau Mergin dan Kualitas Pelayanan Terhadap Minat Anggota Dalam Membeli Produk Pembiayaan Murabahah di Koperasi Jasa Keuangan Syariah (Studi Kasus BMT Amal Mulia) : Skripsi, Jurusan Perbankan Syariah Fakultas Syariah dan Ekonomi Islam STAIN Salatiga Jawa Tengah, 2015, hlm. 28
} 
terhadap minat pembiayaan BSM Implan di Bank Syariah Mandiri cabang Gorontalo.

Dari hasil pengujian secara parsial (uji t) antara variabel penampilan diri dan minat pembiayaan BSM Implan menunjukkan nilai $\mathrm{T}_{\text {hitung }}$ lebih kecil dari pada $\mathrm{T}_{\text {tabel }}$ dengan nilai $1.900<$ 1.996 dan memiliki nilai sig probabiitasnya sebesar

0.062 lebih besar dari 0.05 . Hal ini menunjukkan bahwa variabel penampilan diri tidak berpengaruh signifikan terhadap minat pembiayaan BSM Implan di Bank Syariah Mandiri cabang Gorontalo.

Hal ini sesuai dengan penelitian Sdri Masrifatul Korimah dalam "Faktor- Faktor yang Mempengaruhi Nasabah dalam mengajukan Pembiayaan Mudharabah" bahwa dari hasil penelitian penyusun menyimpulkan faktor pelayanan tidak berpengaruh terhadap minat Nasabah dalam mengajukan Pembiayaan Mudharabah pada BPR Syariah Bangun Drajat Warga. Hal ini dilihat dari nilai signifikansi $0.089>0.05$. Namun pada kasus ini, peneliti mengkhususkan pada satu aspek performa pelayanan yakni penampilan diri.

Alasan yang berikut adalah faktor faktor yang mempengaruhi permintaan suatu produk adalah harga itu sendiri, harga barang lain yang berkaita erat dengan komoditas tersebut, pendapatan rumah tanga dan pendapatan rata rata masyarakat,citra rasa masyarakat dan ramalan mengenai keberadaan dimasa yang akan datang. ${ }^{29}$ Dalam teori ini tidak mengungkapkan adanya faktor pelayanan dengan standar penampilan diri yang mempengaruhi minat atau permintaan nasabah.

\section{Pengaruh Pengetahuan Produk \& Jasa Perbankan terhadap Minat Pembiayaan BSM Implan cabang Gorontalo.}

Penguasaan tentang produk dan jasa beserta prinsip syariah yang terkandung merupakan muatan yang harus dikuasai frontliner dan karyawan bank syariah. Apalagi nasabah yang datang ingin mendapatkan diferensiasi layanan agar terhindar dari riba, spekulasi, disamping keinginan untuk bermitra.

Dari hasil pengujian secara parsial (uji t) antara variabel pengetahuan produk dan jasa perbankan terhadap minat pembiayaan BSM Implan menunjukkan nilai $\mathrm{T}_{\text {hitung }}$ lebih besar dari pada $\mathrm{T}_{\text {tabel }}$ dengan nilai $2.965>1.996$ dan memiliki nilai sig probabiitasnya sebesar 0.004 lebih kecil dari 0.05. Hal ini menunjukkan bahwa variabel pengetahuan produk \& jasa perbankan berpengaruh positif dan signifikan terhadap minat pembiayaan BSM Implan di Bank Syariah Mandiri cabang Gorontalo.

\footnotetext{
${ }^{29}$ Sugiarto dkk, Ekonomi Mikro sebuah Kajian Komperehensif,Jakarta : Pt gramedia pustaka utama, 2007 hal 34
} 
Volume. 15, Nomor 1, Juni 2019

Halaman. 68-88
Pengaruh Penerapan Standar Pelayanan

Terhadap Minat Pembiayaan Produk BSM Implan

di Bank Syariah Mandiri Cabang Gorontato

Secara Kualitatif alasan pengetahuan produk \& jasa perbankan dapat mempengaruhi minat pembiayaan BSM Implan di Bank Syariah Mandiri cabang Gorontalo adalah karena ketika nasabah mendapat rujukan atau solusi dari kebutuhan kemudian menghubungi pihak Bank untuk melakukan konsultasi, hasil dari konsultasi tersebut melahirkan pertimbangan baik dari segi mekanisme pembayaran manfaat mudharat melakukan pembiayaan yang beberapa hal tadi membutuhkan pengetahuan luas dari seorang admin pembiayaan mengenai produk tersebut.

\section{Pengaruh Standar Berkomunikasi dengan Nasabah terhadap Minat Pembiayaan BSM Implan cabang Gorontalo.}

Komunikasi yang baik dengan nasabah dapat membangun kesan positif terhadap bank sehingga turut membantu terbentuknya nasabah yang (loyal costumer).

Dari hasil pengujian secara parsial (uji t) antara variabel standar berkomunikasi dengan nasabah terhadap minat pembiayaan BSM Implan menunjukkan nilai $\mathrm{T}_{\text {hitung }}$ lebih kecil dari pada $\mathrm{T}_{\text {tabel }}$ dengan nilai $0,889<1.996$ dan memiliki nilai sig probabiitasnya sebesar 0.377 lebih besar dari 0.05. Hal ini menunjukkan bahwa variabel standar berkomunikasi dengan nasabah tidak berpengaruh signifikan terhadap minat pembiayaan BSM Implan di Bank Syariah Mandiri cabang Gorontalo.

Hal ini tidak sesuai dengan penelitian Sdri Eva Roviana, Analisis Pengaruh Persepsi Harga atau Margin dan Kualitas Pelayanan terhadap Minat Anggota dalam Membeli Produk Pembiayaan Murabahah di Koperasi Jasa Keuangan Syariah (Studi Kasus BMT Amal Mulia), dalam penelitiannya dikatakan pengaruh yang positif dan signifikan terhadap minat anggota.Kualitas pelayanan adalah elemen terpenting dari setiap perusahaan jasa yang wajib ditingkatkan. Dari hasil penelitian ini, peneliti menemukan bahwa sekitar 52,5\% dari elemen yang mempengaruhi minat nasabah dihasilkan oleh kualitas pelayanan. Dari hasil kuesioner yang diberikan kepada anggota, peneliti menyimpulkan bahwa pelayanan yang diberikan BMT telah dirasakan anggota cukup mampu memberikan kenyamanan dan kepercayaan yang mendorong anggota untuk melakukan pembiayaan murabahah di BMT Amal Mulia.. Dipercaya oleh peneliti bahwa hasil angket pada suatu penelitian dapat merubah tingkat pengaruh dan signifikansi pada satu variabel karena alasan mendasar nasabah yang identik tertarik dengan pembiayaan berdasarkan faktor psikologis dan pribadi nasabah hal ini didapati pada butir pertanyaan 1 (berminat mengajukan pembiayaan karena beragama Islam memperoleh 90\% jawaban setuju dari nasabah implant itu sendiri sehingga dapat disimpulkan timbulnya minat pembiayaan BSM 
Volume. 15, Nomor 1, Juni 2019

Halaman. 68-88
Pengaruh Penerapan Standar Pelayanan

Terhadap Minat Pembiayaan Produk BSM Implan di Bank Syariah Mandiri Cabang Gorontalo

Implan di Bank Syariah Mandiri Cabang Gorontalo dipengaruhi secara positif namun tidak signifikan oleh Standar berkomunikasi admin BSM Implan dengan nasabah.

\section{Pengaruh Performa Pelayanan (Penampilan Diri, Pengetahuan Produk \& Jasa Perbankan, Standar Komunikasi) secara simultan terhadap Minat Pembiayaan BSM Implan di Bank Syariah Mandiri Cabang Gorontalo.}

Dari hasil pengujian secara simultan (uji f) antara variabel independen yaitu Performa Pelayanan (Penampilan Diri, Pengetahuan Produk \& Jasa, dan Standar Bekomunikasi dengan Nasabah) terhadap variabel dependen yaitu minat pembiayaan BSM Implan menunjukkan nilai $F_{\text {hitung }}$ lebih besar dari pada $F_{\text {tabel }}$ dengan nilai 14,715 > 3,14 dan memiliki nilai sig probabiitasnya sebesar 0.000 yang lebih kecil dari 0.05. Hal ini menunjukkan bahwa secara simultan, variabel indapenden yakni Penerapan Standar Pelayanan (Penampilan Diri, Pengetahuan Produk \& Jasa Perbankan, Standar Berkomunikasi dengan Nasabah) berpengaruh secara signifikan terhadap variabel dependen yakni minat pembiayaan BSM Implan di Bank Syariah Mandiri cabang Gorontalo.

Hal ini sesuai dengan penelitian yang dilakukan oleh Ali Chamidun dengan judul Analisis Faktor-Faktor yang mempengaruhi Minat UMKM mengajukan pembiayaan terhadap Lembaga Keuangan Syariah dimana ada 3 faktor yaitu pelayanan, reputasi, dan prosedur secara bersamasama memberikan kontribusi terhadap meningkatnya minat UMKM mengajukan pembiayaan pada lembaga keuangan syari'ah (BMT Barokah Magelang). Dengan besaran pengaruhnya adalah 95,4\%. Dari ke tiga faktor tersebut dapat disimpulkan faktor yang paling dominan mempengaruhi minat UMKM untuk mengajukan pembiayaan pada lembaga keuangan syariah dengan melihat pada uji regresi berganda dengan koefisien beta terhadap masing-masing variabel adalah faktor prosedur, hal ini dikarenakan UMKM pada umumnya ingin memperoleh pembiayaan dengan prosedur yang mudah dan tidak berbelit-belit, faktor selanjutnya adalah reputasi dan pelayanan yang mempunyai pengaruh yang juga cukup signifikan karena lembaga keuangan adalah lembaga yang menjual kepercayaan kepada masyarakat.

\section{Kesimpulan dan Saran}

Berdasarkan hasil penelitian ini dan pembahasan mengenai pengaruh penerapan standar pelayanan terhadap minat pembiayaan BSM Implan di Bank Syariah Mandiri cabang Gorontalo dapat diperoleh kesimpulan sebagai berikut:

1. Tidak terdapat pengaruh secara signifikan variabel Penampilan Diri terhadap Minat 
Pembiayaan BSM Implan.

2. Terdapat pengaruh positif dan signifikan antara pengetahuan produk \& jasa perbankan dan minat pembiayaan BSM Implan.

3. Tidak terdapat pengaruh secara signifikan antara standar berkomunikasi dan minat pembiayaan BSM Implan

4. Terdapat pengaruh yang postif dan signifikan antara variabel Penampilan Diri, Pengetahuan Produk \& Jasa Perbankan, Standar berkomunikasi dengan nasabah terhadap Minat Pembiayaan BSM Implan.

Temuan pada variabel $\mathrm{X} 1$ dan X3 ini tidak sesuai dengan penelitian terdahulu sebab dipercaya oleh peneliti bahwa hasil angket pada suatu penelitian dapat merubah tingkat pengaruh dan signifikansi pada satu variabel karena alasan mendasar nasabah yang identik tertarik dengan pembiayaan berdasarkan faktor psikologis dan pribadi nasabah hal ini didapati pada butir pertanyaan 1 (berminat mengajukan pembiayaan karena beragama Islam) memperoleh 90\% jawaban setuju dari nasabah implant itu sendiri.

Selain itu, penelitian mengenai pelayanan pada umumnya mengungkapkan pengaruh yang signifikan terhadap pembiayaan. Namun kali ini, peneliti menemukan satu gagasan baru bahwa pelayanan jika digeneralisir akan memberikan pengaruh signifikan serta kontribusi yang besar terhadap minat pembiayaan, namun ketika diukur pada aspek atau bagian-bagian dari standar pelayanan belum tentu berpengaruh terhaap minat pembiayaan.

\section{Saran}

Penulis memberikan saran kepada beberapa pihak yakni sebagai berikut :

1. Kepada penulis selanjutnya. Disarankan untuk kepada penulis selanjutnya agar menggunakan taraf tingkat performa pelayanan lebih besar lagi. menggunakan data yang lebih akurat dengan jumlah responden yang lebih banyak. Sebab penggunaan data yang lebih akurat meningkatkan hasil yang baik.

2. Kepada Praktisi Bank. Berdasarkan penelitian ini variabel pengetahuan produk dan jasa perbankan begitu berpengaruh terhadap minat pembiayaan BSM Implan. Maka diharapkan kepada pihak bank agar menjaga pengetahuan admin mengenai produk dan jasa perbankan di bank syariah. Selain itu, penelitian ini menyimpulkan bahwa penampilan diri dan standar komunikasi tidak berpengaruh signifikan terhadap minat pembiayaan BSM Implan. Maka hendaknya Bank Syariah dapat mempertimbangkan untuk meningkatkan kualitas penerapan standar pelayanan terhadap nasabah. 
Volume. 15, Nomor 1, Juni 2019

Halaman. 68-88
Pengaruh Penerapan Standar Pelayanan

Terhadap Minat Pembiayaan Produk BSM Implan di Bank Syariah Mandiri Cabang Gorontato

\section{DAFTAR PUSTAKA}

Abdul Waris, Pengaruh Kualitas Pelayanan dan Penerapan Prinsip-Prinsip Syariah Terhadap Minat Hotel Syariah (Studi Kasus pada Hotel Graha Agung) : Skripsi, Fakultas Ekonomi \& Bisnis Islam IAIN Walisongo Semarang, 2010,

Alfian Nugroho, Pengaruh Kepuasan Akan Kualitas Pelayanan dan Kepercayaan Terhadap Loyalitas Nasabah BPD Kaltim Cabang Utama Samarinda, Jurnal Mahasiswa S1 Administrasi Bisnis Fakultas Ilmu Sosial dan Ilmu Politik Universitas Mulawarman,

Ali Chamidun, Analisis Faktor-Faktor yang Mempengaruhi Minat UMKM Mengajukan Pembiayaan pada Lembaga Keuangan Syariah : Skripsi, Jurusan Perbankan Syariah Fakultas Syariah dan Ekonomi Islam STAIN Salatiga Jawa Tengah, 2015,

Andi Mappiere, Psikologi Orang Dewasa Bagi Penyesuaian Dan Pendidikan, (Surabaya: Usana Offiset Printing, 1994)

An-Nawawi, Al-Imam Abi Zakaria Yahya bin Syarof, Terjemah Riyadhus Shalihin jilid 1, (Jakarta: Pustaka Amani, 1994),

Departemen Agama RI, Al-Qur'an dan Terjemahnya Yasmina, (Bandung: PT Sygma Examedia Arkanleema, 2009),

Eva Roviana, Analisis Pengaruh Persepsi Harga atau Mergin dan Kualitas Pelayanan Terhadap Minat Anggota Dalam Membeli Produk Pembiayaan Murabahah di Koperasi Jasa Keuangan Syariah (Studi Kasus BMT Amal Mulia) : Skripsi, Jurusan Perbankan Syariah Fakultas Syariah dan Ekonomi Islam STAIN Salatiga Jawa Tengah, 2015,

Ikatan Bankir Indonesia, Memahami Bisnis Bank Syariah, (Jakarta: PT Gramedia Pustaka Utama, 2016), hal. 296-297

Julita, Menuju Kepuasan Pelanggan Melalui Penciptaan Kualitas Pelayanan, Jurnal Ilmiah "Manajemen dan Bisnis", Vol. 01, No.01, 2001,

Nofri Boy Sandi, Analisis Pengaruh Pelayanan, Konsultasi, dan Pengawasan Account Representative Terhadap Kepatuhan Wajib Pajak : Skripsi, Jurusan Akuntansi Fakultas Ekonomi dan Bisnis Universitas Islam Negeri Syarif Hidayatullah Jakarta, 2010

Philip Kotler, Manajemen Pemasaran edisi Milenium I, (Jakarta: PT Prenhalindo, 2002)

Rahmayanti Lisa, Pengaruh Kualitas Layanan Rawat Inap terhadap Kepuasan Pasien Rumah Sakit Bunda Margonda Depok : Skripsi, Fakultas Ekonomi dan Bisnis Univesitas Indonesia, Depok, 2009. 
Shaleh, Psikologi Suatu Pengantar (Dalam Perspektif Islam), (Jakarta: Prenada Media, 2004)

Sugiarto dkk, Ekonomi Mikro sebuah Kajian Komperehensif,Jakarta : Pt gramedia pustaka utama, 2007

W.J.S Poerwardaminta, Kamus Besar Bahasa Indonesia, Edisi III (Jakarta: Balai Pustaka, 2006)

Zeithaml, Service Marketing: Integrating Customer Focus Across The Firm, Fifth Edition, (New York: McGraw-Hill Companies, 2009), 